pítulo. Conseqüentemente, é um livro que se pode indicar, com prazer, para cursos de produção de nivel médio, superior, de pós-graduação em administraçăo de empresas, e de especialização em cursos de engenharia.

Kurt E. Weil
Planejamento empresarial

Por Russel L. Ackoff. Trad. de Marco Tulio de Freitas do original norte-americano A concept of corporate planning. Wiley, 1970. Rio de Janeiro, Livros Técnicos e Científicos, 1974. 126 p. + XII. Ed. il. Bibliografia e indice analítico.

O título em inglês dá sem dúvida, uma melhor visão da obra: corporate planning, ou seja, planejamento de grandes empresas (corporations) não só de empresários, que incluem desde o vendedor por conta própria, como por exemplo o pipoqueiro da esquina, até o diretor-proprietário de um império fabril. Ainda concept, traduzivel como conceito, dá uma conotação de que é importante localizar no livro a área conceitual em prejuízo eventual da área técnica de planejamento. O autor preocupa-se mais com o porqué, em lugar de como, quanto e quando. Assim, por exemplo, tratando do planejamento de materiais e suprimentos, na página 33, com alusão especifica a "modelos de fornecimento" ele declara: "Não é de todo incomum as empresas presumirem, mesmo de maneira implícita, que haverá sempre matéria-prima"' para dizer, em seguida, que válvulas foram substituidas por transistores, um tipo de sementes por outro - para terminar de novo no autofornecimento. $\mathrm{Na}$ página 47: "Os insumos necessários (...) talvez não apresentem nenhum problema (...) Mas mesmo onde a disponibilidade não for problema, os custos destes suprimentos podem estar sujeitos a mudanças substanciais. Aumentos possiveis podem (...) justificar uma procura de materiais substitutos ou para se considerar a produção da matéria-prima. Os planejadores devem sempre examinar a viabilidade integração vertical na parte de insumos." Assim - agora sem exemplos - ele acaba falando de compras. Nota-se que trata do problema genericamente, não especificamente, como planejar para integrar verticalmente: quais os custos, quais as experiências, por exemplo, da Cia. Souza Cruz (fumo no Brasil) que não se integrou, e a Firestone, que procurou a integração vertical, com resultados negativos, e a Cia. Siderúrgica Nacional (CSN) a que teve resultados positivos. Observa-se, portanto, que em lugar de se aprofundar, o estudo é realizado em bases filosóficas.

Numa apreciação global, pode-se perceber que o autor conseguiu o que está explicado no lombo da capa da brochura - "pode ter sido mais uma filosofia de planejamento do que um guia'. Realmente, livros-guia existem muitos, e devido ao seu conteúdo altamente matemático, quasë nenhum empresário pode lèlos. Além disso, a utilidade prática de tais livros torna-se muito restrita se levarmos em conta que os recursos materiais e humanos para um planejamento global, e a longo prazo faltam muitas vezes ao empresário.

Assim, o primeiro capítulo A natureza e o conteúdo do planejamento - define conceitos e discute a extensão da divisão do planejamento. Gostei imensamente dessas definiçбes, pois o autor reconhece o alto grau de indefinição, como, por exemplo, quando diz que entre o tático e 
- estratégico existem passagens intermediárias difíceis de se enquadrar.

O tratamento da adaptação no planejamento está excelente, pois o autor torna claro que o valor do planejamento não está nos planos que produz, mas no processo de produzi-los e menciona o quinto plano francês citado por Eric Trist que, por sua vez, cita Crozier. Devido a essa passagem lingüística, o plano se torna Plano $5^{\mathrm{e}} \mathrm{e}$, numa tradução incompleta do francês, cinquième. Em seguida, continua dizendo que toda a necessidade atual de planejamento provém da falta de administração e controles eficazes, para concluir que o bom (destaque meu) planejamento a longo prazo envolve, entre outras coisas: a) descobrir o inevitável; b) determinar como explorá-lo; e c) receber crédito por tê-lo descoberto.

o capítulo 2 - Objetivos e metas - tem uma seção digna de nota sobre Solução de conflitos entre objetivos e os demais capítulos são:

3. Politicas e alternativas de ação.

4. Planejamento de recursos.

5. Estrutura organizacional.

6. Controle.

7. A organização do trabalho do planejamento.

o capítulo sobre controle começa enfatizando a necessidade de informações relevantes e declara, muito sabiamente, que só é possivel chegar a alguma conclusão sobre a necessidade de determinada informação caso for testado após sua elaboração. O que demonstra o acerto do método simplificatório de $O$ \& $M$, a saber, o teste de uso. Se ninguém usar a informação durante seis meses, ela pode ser eliminada.

Uma pequena nota explica como funciona uma assessoria de planejamento e inúmeros organogramas e fluxogramas completam o livro, que termina citando $\mathrm{A}$ arte da guerra de Sun Tzu, que viveu de 400 a 320 A.C.: "Com muitos cálculos pode-se vencer; com poucos, não se pode. Que chances a menos de vitória tem quem não faz nenhum cálculo."

Tendo assim demonstrado, a contento e historicamente, que meter os peitos pode dar certo mas na maioria das vezes não dá, Ackoff deu um valiosíssimo livro ao empresário.

As referências à prática são, neste caso, norte-americanas, e os casos contados são apropriados, mas infelizmente o tradutor não colocou exemplos nacionais no rodapé. A tradução é muito correta e agradável. O livro tem muito mais conteúdo do que deixam suspeitar as magras 126 páginas. A impressão é muito clara e nitida, apesar do tamanho das letras ser aparentemente Concorde 19155 letras $/ 9 \mathrm{~cm}$. Portanto, a apresentação gráfica e dos desenhos e tabelas acompanha a boa impressão que se recebe deste livro. Em escolas de administração pública e de empresas, em faculdades de engeriharia, em planejamento hospitalar, em todas as áreas enfim, onde o planejamento entra de uma ou outra maneira (quantitativamente ou qualitativamente), recomenda-se 0 livro como leitura. A sabedoria está tão concentrada que é extremamente difícil dar expressão à riqueza de conceitos transmitidos. Se nessa crítica não é possivel citar interminavelmente o autor, inclusive porque os direitos autorais proíbem tal, ao menos tentei dar a pálida impressão do semblante da sabedoria do autor.

Kurt E. Weil

\section{The management of production}

J. D. Radford \& D. B. Richardson, 2. ed. London, New York, MacMillan, St. Martin Press, 1968. VIII + 320 p., 144 il. bibl. $\mathrm{p} /$ cap. Índice remissivo, 36 shillings.

Os autores pertencem ao departamento de engenharia mecânica e de produção do Brighton College of Technology, são engenheiros e têm prática industrial por meio de consultoria em diversas empresas inglesas. O livro foi escrito com a principal finalidade de preparar estudantes para o exame final em administração industrial e igualmente para a análise de sistemas de manufatura. Assim, recomenda-se para estudantes em administração e engenharia. Tem ainda como destino servir de livro de cabeceira para pessoal de controle físico ou financeiro da produção.

O conteúdo do livro acompanha a escola clássica de ensino de administraçăo da produção. Não deve causar dificuldade o uso de uma linguagem técnica inglesa, levemente diferente da norteamericana, pois a terminologia segue o padrão britânico B. S. 3138:1959 do estudo do trabalho. Os 20 capítulos do livro são os seguintes: 